\title{
液晶マイクロレンズ不規則配列セルの光散乱効果
}

\author{
能 勢 敏 明 ${ }^{\dagger}$, 正会員 佐 藤 進 ${ }^{\dagger}$

\section{Light Scattering Effects in a Randomly Arranged Liquid Crystal Microlens Array}

\author{
Toshiaki Nose ${ }^{\dagger}$ and Susumu Sato ${ }^{\dagger}$
}

\begin{abstract}
An axially symmetric non-uniform electric field is produced in a liquid crystal cell with a hole -pattern electrode structure, and a lens-like property ; that is, a liquid crystal microlens is created by the molecular orientation effects in the non-uniform electric field. This lens-like property can be widely changed by varying the applied voltage, and the focal length of this liquid crystal microlens is so short that light scattering properties are obtained. A scattering type of display device can be attained by fabricating a number of microlenses in a cell. By arranging the liquid crystal microlenses randomly, interference effects can be eliminated and the quality of images observed through the liquid crystal cell is greatly improved, compared to a well-ordered microlens array.
\end{abstract}

\section{1. まえがき}

通常の液晶表示素子は, 透明電極を塗布した一対の ガラス基板間に液晶材料を封入した素子構造を有し， 平行平板電極間に生ずる均一な電界中での液晶分子配 向効果に基づく電気光学効果を利用している. 一方, 円形穴形パターン電極を用いた液晶セルでは, パター ン部分に軸対称状の電界が生じるが，このような不均 一電界中での液晶分子配向効果により空間的な屈折率 分布が生じ, したがって, レンズ効果（液晶マイクロ レンズ）が得られることが知られている11.

液晶マイクロレンズは, 印加電圧によって光学的特
性が大幅に変化するため, 光ファイバスイッチ等の新 しい液晶光学素子への応用が期待される ${ }^{2) ~ 4) . ま た, ~}$ 液晶マイクロレンズの焦点距離は非常に短く, セルを 透過する光の散乱効果が得られるため, 多数の液晶マ イクロレンズを配列した液晶セルを用いて光散乱型の 表示素子への忘用の可能性が検討されている ${ }^{5 / 6)}$. こ の場合, 小さな印加電圧で急峻な闇特性が得られ, そ の特性は光の入射角度にあまり依存しないため, 広い 視野角が期待される。また，ITO等の透明電極を用 いた場合には, 円形穴形の直径と間隔を変えることに より入射光の散乱・非散乱成分の割合を容易に調整す ることができる半透明表示素子への応用も期待され

キーワード: 液晶, マイクロレンズ, 光散乱, 表示素子

1990 年 10 月 29 日, 電子情報通信学会技術報告, EID90-62 に発表

1992 年 9 月 4 日受付

$\dagger$ 秋田大学 鉱山学部電子工学科 ( \% 010 秋田市手形学園町 1-1, TEL 0188-33-5261)

$\dagger$ Department of Electronics, Akita University (Tegatagakuen-cho 1-1, Akita-shi, Akita 010, Japan) 
る.しかし, 円形穴形パターンを規則正しく配列した 場合には, 各々のパターンからの透過光の干渉効果に より, 電圧無印加時の透明状態あるいは適当な電圧印 加による半透明状態において, 液晶セルを通して観察 した物体像の著しい劣化が生じた。

本研究では，このような問題を解決するために, 円 形穴形パターンを不規則に配列した電極パターンを用 いて液晶セルを作製し, 種々の光学的特性の測定を行 った。

\section{2. 液晶マイクロレンズ}

円形穴形パターン電極と透明平板電極を組合せた非 対称な電極構造を有する液晶マイクロレンズでは, セ ル内に軸対称状の不均一電界が生じる.このような電 界分布に扔ける種々の電界強度での液晶分子配向モデ ルを図 $1(\mathrm{a})$ ～( c ) に示す. p 型ネマティック液晶を 用いて分子長軸が基板に平行に配向するようにホモジ ニアス配向処理を行った場合には, 印加電圧 $0 \mathrm{~V} に$ おいて図 1 (a) に示すような一様に基板に平行な配向 状態になると考えられる. この時, 偏光方向が分子長 軸に平行な入射光に対して空間的に一様に大きな屈折 率 $n_{e}$ (異常光屈折率) を示す.一方, 液晶セルに小さ な電圧を印加した場合の分子配向モデルを図 1 ( b ) に 示すが, 電界の集中する円形パターン端付近の液晶分 子から電界方向に配向し始め, 電界強度の分布特性に 応じた液晶分子の配向角分布が生じる.したがって, この場合にはパターン中央に近づくにつれて大きくな るような凸レンズとしての屈折率分布特性が得られ る.

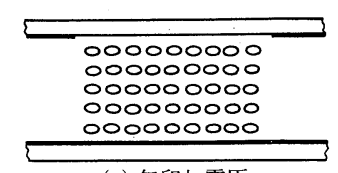

(a) 無印加電圧

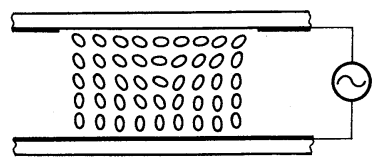

(b) 低印加電圧

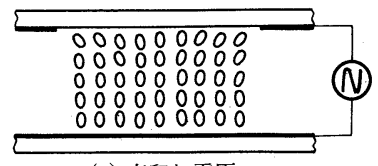

(c) 高印加電圧

図 1 液晶分子配向モデル

A liquid crystal molecular orientation model.
液晶セルに充分大きな電圧を印加した場合には, 図 1 (c) に示すようにほとんどすべての領域で液晶分子 は電界方向に配向すると考えられる。この場合, 低印 加電圧の時とは逆に中央ほど屈折率が小さい, 凹レン ズとしての屈折率分布特性が得られる.

このように, 液晶マイクロレンズは印加電圧によっ てその特性を, 素通し, 凸レンズ, 凹レンズの間で大 幅に変化させることができる。また, 構造が単純なた め, 容易に微細化, アレイ化が行える特徵を有する.

\section{3. 実験}

コンピュータを用いて円形究形の中心座標を不規則 に分布させることにより, 不規則配列パターンを作製 した.ここで, 円形穴形領域の面積を電極全体の $50 \%$ とした. 一方, 規則配列パターンの場合には, 最 近接円形パターンどうしの中心を結ぶ線が正方形の格 子状になるように配列し, 穴形半径/中心間距離の比 を 0.4 とすることにより穴形領域の面積を $50 \%$ とし ている.また，対向電極として ITO 透明平板電極を 用いた. 両電極基板の表面にポリビニールアルコール （PVA）塗布およびラビング処理を行った後, 適当な 厚みのスペーサを介して両基板を接着し, $\mathrm{p}$ 型ネマテ イック液晶 K $15(\mathrm{BDH})$ を封入してホモジニアス配向 液晶セルを作製した。

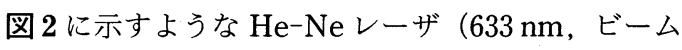
径約 $1 \mathrm{~mm}$ ）および $\mathrm{Si}$ ホトダイオードを用いたシステ ムにより, 液晶セルの透過光強度特性の測定を行っ た。また，液晶セルを通して実際に印刷文字の観察を 行い, 規則配列パターンを有する液晶セルの場合との 比較検討を行った.

\section{4. 光散乱特性}

液晶セルの印加電圧に対する透過光強度特性の測定 例を図 3 に示す．図中のパラメー夕は液晶セルと光検 出器との距離 $L$ を表す．比較的低い印加電圧におい

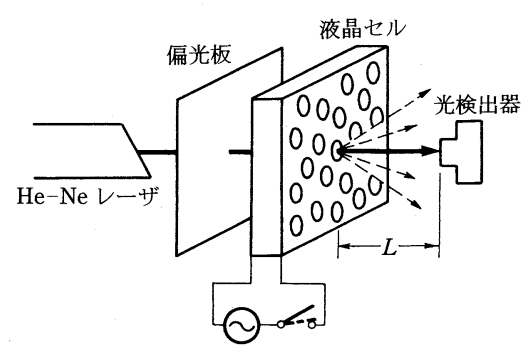

図 2 測定システム

A measuring system. 


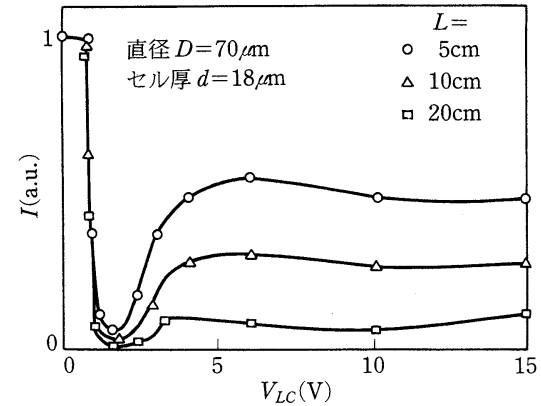

図 3 電圧-透過光強度特性 (入射光の偏光方向が分子 配向方向と平行 : 異常光)

Voltage dependence of the transmission light intensity (extraordinary ray).

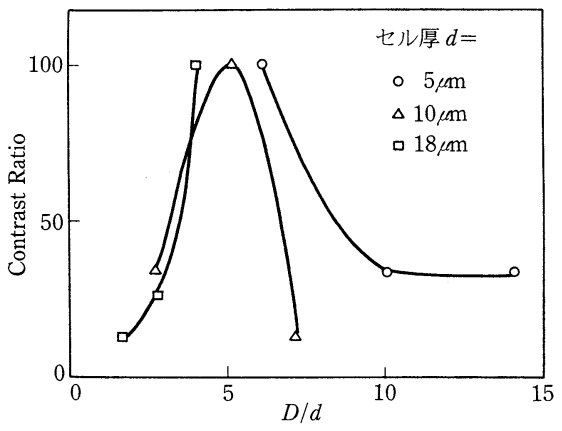

図 4 円形パターン直径とセル厚の比 $(D / d)$ に対する コントラスト比

Contrast ratio $v s$. the ratio of the diameter of the hole pattern to the thickness of the cell.

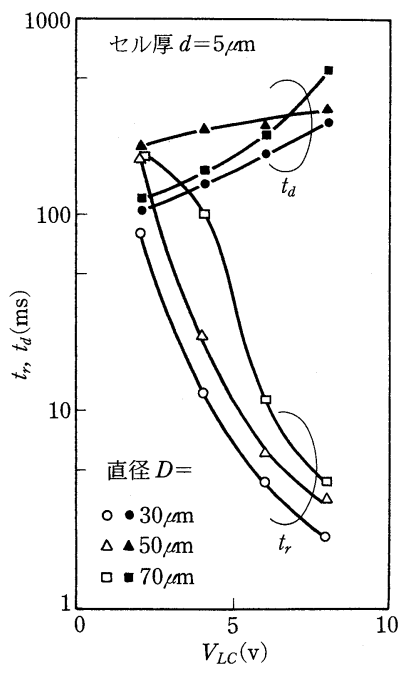

図 5 印加電圧-応答・回復時間特性（セル厚 $5 \mu \mathrm{m}$ ) Response and recovery times $v s$. applied voltage.
て, 凸レンズ特性に起因する光散乱効果により, 透過 光強度が急激に低下する様子が見られる. 透過光強度 は 1 2 V 程度で最小となり, 印加電圧が大きくなる と再び上昇し, その後ほぼ一定となる結果が得られ た。この高印加電圧における飽和した光散乱特性は, 凹レンズ特性により生じると考えられる.

種々のパターン直径およびセル厚の液晶セルにおい て, 透過光強度の最大値と最小值の比をコントラスト 比とし, 円形パターン直径とセル厚の比 $(D / d)$ に対 してまとめた結果を図 4 に示す。ここで, 液晶セルと 光検出器との距離は $20 \mathrm{~cm}$ であり, また図中のパラ メータ $d$ は液晶セルの厚みを示す. パターン直径と セル厚の比 $(D / d)$ が $5 \sim 6$ においてコントラスト比 が非常に大きくなる傾向が見られた，液晶マイクロレ ンズの特性は, セル内の電界分布により大きく影響を 受け, したがって, これらの光散乱特性は $D / d$ の值 により大きく変化するものと考えられる。レンズ単体 の集光特性の測定では, $D / d=10$ 程度で最も良好な レンズ特性が確認されているが, この場合には厚みに 対して穴形直径がより小さい $D / d=5 \sim 6$ 程度の条件 で最も大きな光散乱効果が得られることがわかる。

規則配列の場合にも, 同様に $D / d=5 \sim 6$ 程度で光 散乱効果が最大となる傾向が見られているが, コント ラスト比は不規則配列の場合より大きな值が得られて いる．これは，後述するように，規則配列の場合には 出射光が配列したスポット状パターンとなり，スポッ 卜位置に光検出器を設置して測定を行うため, 見かけ 上コントラスト比が大きな值となっているものと思わ れる。

また, 光散乱効果が常光に対しても得られ, 光の入 射角にほとんど依存しない等の特徴は, 不規則配列パ ターンを用いた場合にも同様に見られた。

次に, 応答・回復特性の測定を行い, 透過光強度の 10 90\%変化に要する時間を応答 $\left(t_{r}\right)$ および回復時 間 $\left(t_{d}\right)$ とし, 種々の液晶セルに対してまとめた結果 を図 5 に示す．セル厚が薄くあるいはパターン直径が 小さくなると共に穴形パターン部の電界は大きくなる と考えられ, 応答, 回復特性共に速くなる傾向が見ら れた。また，印加電圧を大きくした場合に，応答特性 は非常に速くなるが回復特性はやや遅くなる傾向が見 られた。

以上の特性には, 液晶マイクロレンズの特性が直接 影響していると考えられ, 穴形直径やセル厚等のパラ メータの変化に対して得られる光散乱効果は, 規則配 列パターンの場合5)6) とほほ同様の傾向が得られた. 


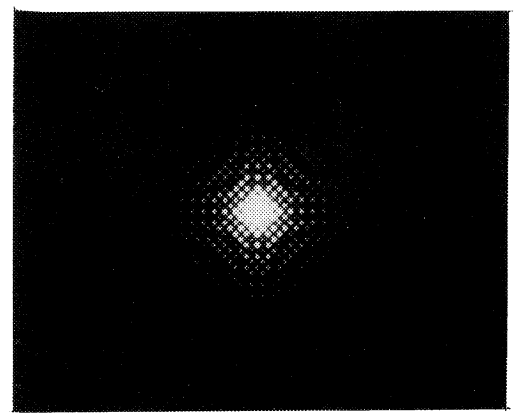

(a) $0 \mathrm{~V}$

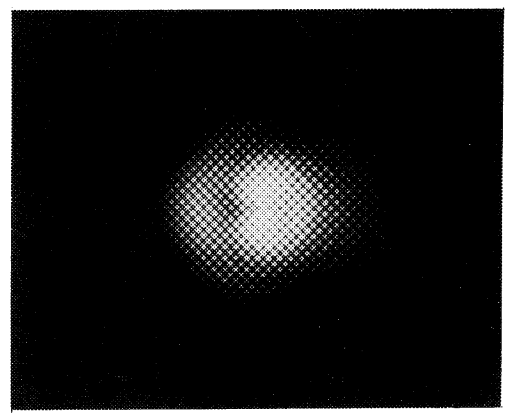

(c) $3.5 \mathrm{~V}$

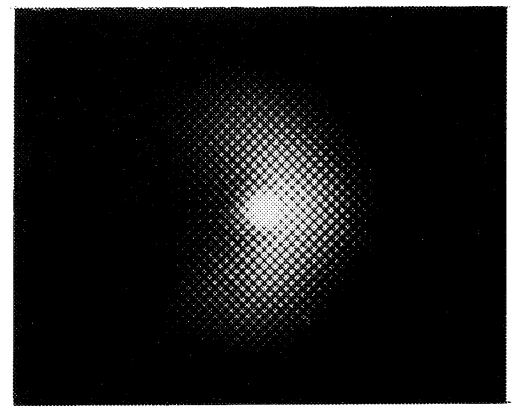

(b) $1.5 \mathrm{~V}$

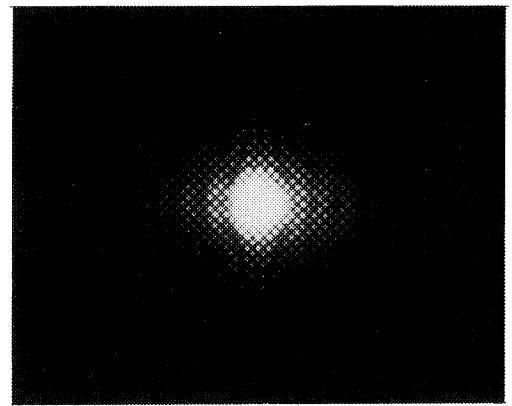

(d) $10 \mathrm{~V}$

写真 1 規則配列セルにおける光散乱パターン（直径 $50 \mu \mathrm{m}$, セル厚 $5 \mu \mathrm{m}$ )

Light scattering patterns through the cell prepared by arranging the hole patterns in good order.

\section{5. 透 過 特 性}

前述の光散乱特性の測定では, 配列パターンの違い による顕著な差は見られなかったが，実際に液晶セル を通して観察する物体像には非常に大きな違いが見ら れた．そこで, 液晶セルを透過したレーザ光の散乱パ ターンの観察, および白色光で照明した印刷文字の液 晶セルを通しての観察を行った。

規則配列パターンを有する液晶セルに垂直に $\mathrm{He}^{-}$ Ne レーザを入射し, 種々の印加電圧において $40 \mathrm{~cm}$ 離れたスクリーンに透過光を投影した結果を写真 1 (a) 〜 (d) に示す. ここで, 入射光の偏光方向は液晶 分子配向方向と一致させた. 配列した穴形パターンか らの干渉効果により規則正しく並んだ多数の輝点が見 られる。電圧を印加すると散乱効果により明るい輝点 の領域が大きくなり，中央付近では明るさが低下する 様子が観察された．さらに印加電圧を大きくすると， 明るい輝点の領域は次第に小さくなり, これは透過光 強度特性において一度極小を通る変化特性に対応した 動きと考えられる，また，大きな電圧を印加した場合 には液晶分子がほぼ電界分布に沿って配向すると考え られ, 明るい領域は次第に軸対称状に近づく様子が見 られる。

論 文ロ液晶マイクロレンズ不規則配列セルの光散乱効果
同様に，不規則配列パターンを有する液晶セルの透 過光の投影像を写真 $2(a) \sim(d)$ に示す. 円形パター ン直径およびセル厚は写真 1 の場合と同一である. 写 真 1 に見られたような輝点の配列は現れず, 一様に広 がった明るい領域が観察された。この明るい領域は印 加電圧が $2 \mathrm{~V}$ 程度で最大となり, この付近で最大の 光散乱特性が得られることに対応していると思われ る. 印加電圧が大きくなると写真 1 の場合と同様に, 明るい領域は次第に軸対称状となる結果が得られた.

次に, 規則配列パターンを有する液晶セルを通し て, 液晶セルから $5 \mathrm{~cm}$ の距離にある白色光照明の印 刷文字を種々の印加電圧において観察した結果を写真 $3(\mathrm{a}) \sim(\mathrm{d})$ に示す.ここで, 入射光の偏光方向が液 晶分子の配向方向と一致するように設定した. 散乱効 果が小さく高い透過率を示す印加電圧 $0 \mathrm{~V}$ の透明状 態および印加電圧の小さい半透明状態においても, 各 穴形パターンからの透過光の干渉効果により文字の像 が不鮮明となっている。すなわち, 透過光像が究形パ ターンの配列の周期性により変調され，モザイク状と なるため視認性が非常に悪化していることがわかる． 印加電圧を大きくすると光散乱効果により文字像がモ ザイク状のまま次第に消えていく様子が観察される。

同様に，不規則配列パターンを用いた場合の結果を 


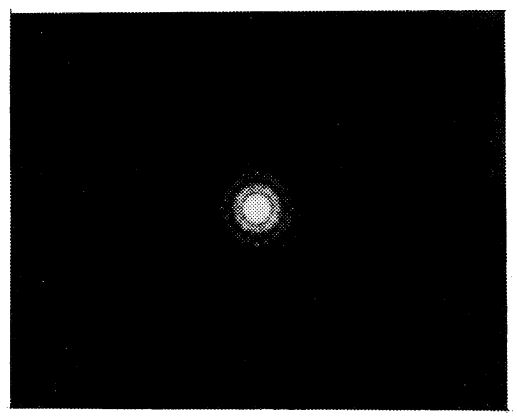

(a) $0 \mathrm{~V}$

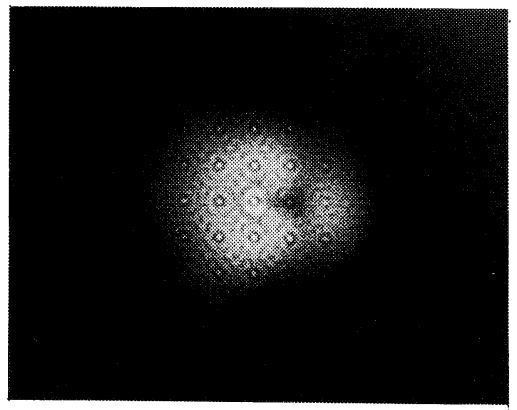

(c) $2.5 \mathrm{~V}$

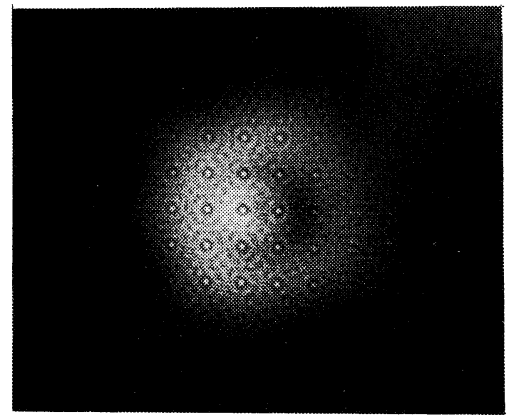

(b) $2 \mathrm{~V}$

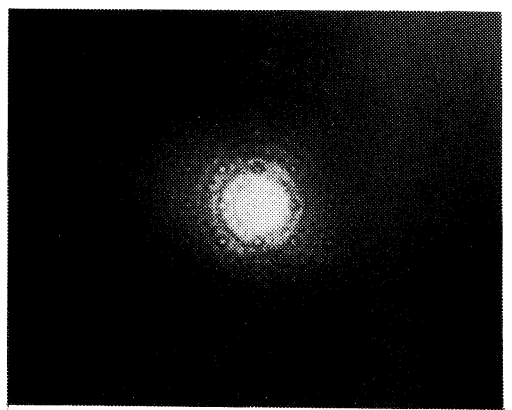

(d) $10 \mathrm{~V}$

写真 2 不規則配列セルにおける光散乱パターン

Light scattering patterns through the cell prepared by arranging the hole patterns randomly.

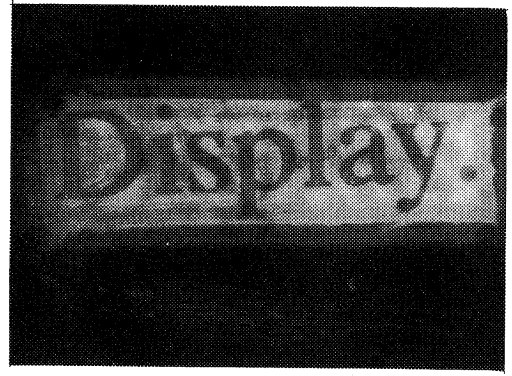

(a) $0 \mathrm{~V}$

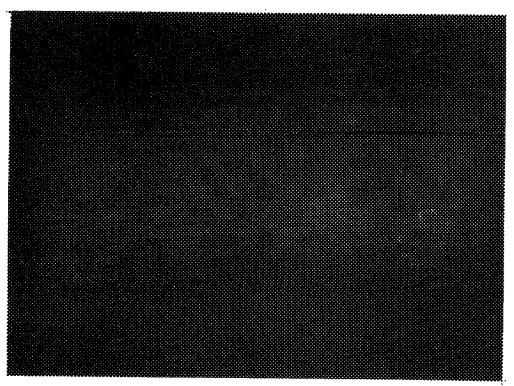

(c) $1.5 \mathrm{~V}$

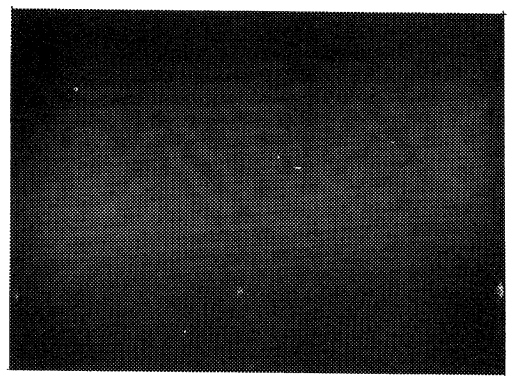

(b) $1 \mathrm{~V}$

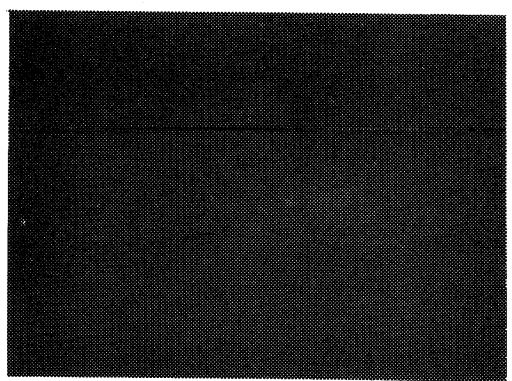

(d) $2 \mathrm{~V}$

写真 3 規則配列セルにおける透過光像（直径 $50 \mu \mathrm{m}$, セル厚 $5 \mu \mathrm{m}$ ）

Some character images through the cell prepared by arranging the hole patterns in good order. 


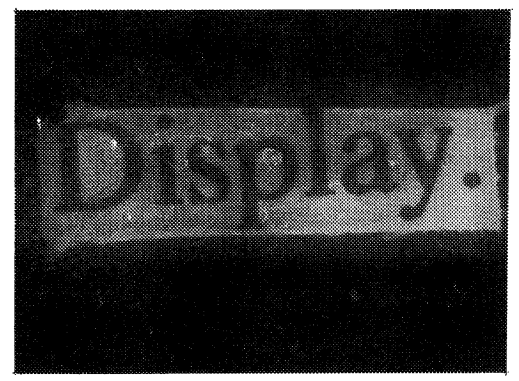

(a) $0 \mathrm{~V}$

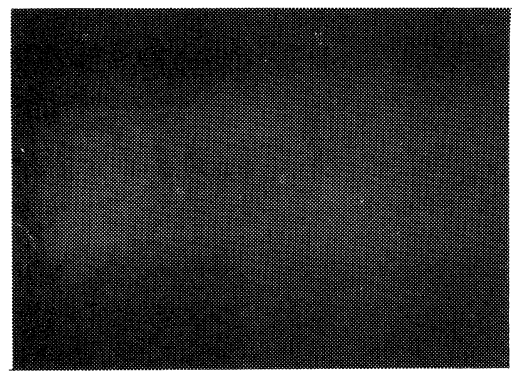

(c) $1.5 \mathrm{~V}$

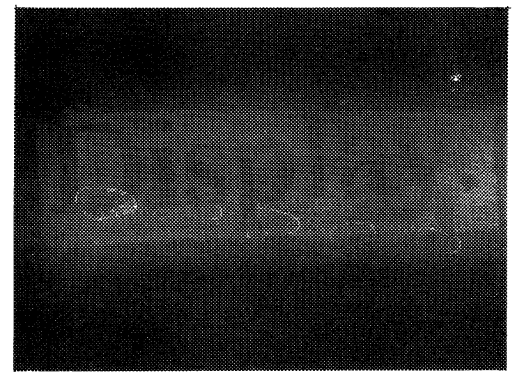

(b) $1 \mathrm{~V}$

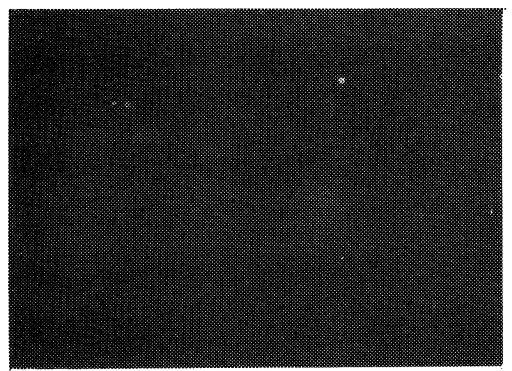

(d) $2 \mathrm{~V}$

写真 4 不規則配列セルにおける透過光像

Some character images through the cell prepared by arranging the hole patterns randomly.

写真 4( a ) （ d )に示す. セル厚およびパターン直径 は写真 3 の場合と同一である. 電圧を印加しない透明 状態や半透明状態において文字像が非常に鮮明となっ ていることが確認された，また，電圧印加と共に光散 乱効果により文字像が次第に見えなくなる様子が観察 され，規則的配列パターンの場合のように透過率がそ れほど低下していないにもかかわらず視認性が急激に 低下する現象は見られず, 図 3 で測定された透過光強 度の低下に応じて次第に像が消えて行く様子が見られ る.

\section{6.む す び}

円形穴形パターンを不規則に配列した $\mathrm{Al}$ 蒸着膜に よるパターン電極基板と ITO 透明平板電極を組合せ てホモジニアス配向の液晶セルを作製し, 種々のパタ ーン直径, セル厚での光散乱特性の測定を行った.

入射光の異常光成分に対して非常に鋭い閾特性およ び高コントラスト比が得られた。

セル厚を薄く, パターン直径を小さくすることによ り, 比較的低い印加電圧で速い応答特性が得られた。

不規則な配列パターンを用いることで, 電圧無印加 時や低電圧印加時に液晶セルを通して観察した物体像 が非常に鮮明となり, 透過特性が大幅に改善された。

パターン配列の違いの実際の透過特性に対する影響 について, 今後定量的な評価が必要と思われる。ま
た, 偏光依存性のない素子の実現等も今後の課題で る.

\section{〔参 考 文 献〕}

1) T. Nose and S. Sato: "A Liquid Crystal Microlens Obtained with a Non-Uniform Electric Field", Liquid Crystals, 5, 5, pp. 1425-1433 (1989)

2）能勢, 佐藤：“ネマティック液晶素子による光ファイバスイ ッチ”，信学技報, EMC88-42, pp. 7-12 (1989)

3) 能勢, 佐藤：“液晶マイクロレンズの特性と光ファイバスイ ッチへの応用”, 信学論, J75-C-I, 3, pp. 155-163 (1992)

4) T. Nose and S. Sato: "Optical Properties of a Liquid Crystal Microlens", Proc. SPIE, 1230, pp. 17-20 (1990)

5）能勢, 佐藤：“液晶マイクロレンズ効果による光散乱特性”, 信学技報, EID88-4, pp. 23-28（1988）

6) T. Nose and S. Sato: "LCD Devices Obtained Using Scattering Properties of Microlens Effects", Proc. SID, 32, 3, pp. 177-181 (1991)

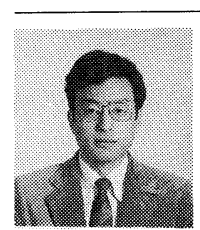

能勢 敏明 昭和 58 年, 東北大学工学部 電気工学科卒業. 昭和 60 年, 同大学院修士 課程修了. 同年, 秋田大学鉱山学部, 電子工 学科助手. 以来, 液晶の光学素子への応用に 関する研究に従事. 現在, 同大学講師.

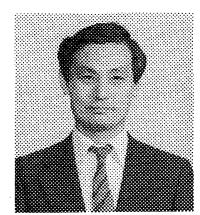

䓜藤進 昭和 39 年, 東北大学工学部 電子工学科卒業. 昭和 44 年, 同大学大学院 博士課程修了. 同年, 同大助手. 昭和 54 年 $\sim 55$ 年, 米国テンプル大客員研究員. 以来, 有機物レーザ材料, 液晶デバイス，EC 材料 などの研究に従事. 現在, 秋田大学鉣山学部 電子工学科教授. 工学博士. 正会員. 